\title{
THE INFLUENCE OF DIETARY PROTEIN ON PLASMA LIPIDS IN HUMAN SUBJECTS
}

\author{
By GILBERT A. LEVEILLE, HOWERDE E. SAUBERLICH, RICHARD C. POWELL* \\ AND WILLIAM T. NUNES
}

(From the U.S. Army Medical Research and Nutrition Laboratory, Fitzsimons General Hospital, Denver, Colo.)

(Submitted for publication October 31, 1961 ; accepted January 18, 1962)

Most studies concerning the influence of dietary protein on serum or plasma lipids have been conducted with experimental animals. A hypocholesterolemic effect has been demonstrated for high dietary protein levels in growing swine, rats, and chicks (1-6). In the rat a hypercholesterolemic diet, containing cholesterol, or cholic acid, or both, is required to demonstrate a substantial depressant effect of high protein on cholesterol; however, this effect has been demonstrated in swine and chicks fed essentially cholesterol-free diets $(1,3,4)$. Certain studies have indicated that the hypercholesterolemic effect of low protein is primarily the result of a sulfur amino acid deficiency; Cebus monkeys $(7)$ and rats $(8,9)$, receiving diets adequate in choline but deficient in sulfur amino acids, develop a hypercholesterolemia that can be overcome by the addition of methionine to the diets. It has been further demonstrated that the serum cholesterol depression resulting from methionine supplementation of a deficient diet is independent of the growth response observed $(8,10)$ in growing animals.

Methionine supplements appear to function differently in choline-deficient rats. Rats fed diets deficient in choline and sulfur amino acids have shown lowered serum cholesterol and elevated liver cholesterol levels; dietary supplementation of either sulfur-containing amino acids, or choline, or both to such animals results in a return of serum and liver cholesterol values to normal levels $(11,12)$. This hypocholesterolemia resulting from a choline deficiency has not been observed in the chick (6), probably owing to the lack of a lipotropic effect of choline in this species as compared with the rat (13).

Studies on the influence of dietary protein and

\footnotetext{
* Present address: 4314 North Sherman Drive, Indianapolis, Ind.
}

lipotropic factors in human subjects have provided less conclusive results than have animal studies. The influence of dietary protein, if any, appears to be of a lesser magnitude in man. Keys and Anderson (14) observed no differences in the serum cholesterol levels of subjects consuming diets supplying 84 or $131 \mathrm{~g}$ of protein and 20 per cent of the total calories as fat. Albanese, Higgons, Lorenze and Orto (15), however, noted that the serum cholesterol levels of elderly patients frequently were elevated by increased protein intakes. Olson (16) fed diets supplying $100 \mathrm{~g}$ of protein per day followed by isocaloric, iso-fat diets supplying $25 \mathrm{~g}$ of protein per day to 9 subjects. The lower serum cholesterol levels observed during the low protein intake were attributed to a low dietary level of choline and sulfur-containing amino acids. In a more recent study Walker, Morse and Overley (17) fed two groups of young female subjects diets supplying 45 to $50 \mathrm{~g}$ of protein per day from animal or vegetable sources. The serum cholesterol level decreased in both groups but more so in the group receiving vegetable protein.

In view of the existing controversy concerning the influence of dietary protein on serum lipids in man, the present study was initiated. The results reported were obtained in a carefully controlled study employing young male volunteers as subjects.

\section{EXPERIMENTAL METHODS}

The subjects for this study were 7 healthy, young, male volunteers, whose average age was 21.6 years (range, 19 to 23). Their average initial weight was $77.4 \mathrm{~kg}$ (range, 70.2 to 97.5). The subjects were housed in a metabolic ward and were permitted off the ward for supervised activity. Body temperature, blood pressure, and body weight were recorded daily for each man.

The study was divided into three 4-week periods during which the subjects received low, high, and low protein diets, respectively. Four menus were developed and were fed in repeated sequence throughout the study 
TABLE I

Daily menus

\begin{tabular}{|c|c|c|c|c|c|c|c|}
\hline \multicolumn{2}{|l|}{ Menu I* } & \multicolumn{2}{|l|}{ Menu II* } & \multicolumn{2}{|l|}{ Menu III* } & \multicolumn{2}{|l|}{ Menu IV* } \\
\hline \multicolumn{8}{|c|}{ Breakfast } \\
\hline $\begin{array}{l}\text { Grapefruit } \\
\text { Bread } \\
\text { Margarine } \\
\text { Jelly, grape } \\
\text { Sucrose }\end{array}$ & $\begin{array}{r}200 \\
20 \\
10 \\
10 \\
120\end{array}$ & $\begin{array}{l}\text { Applesauce } \\
\text { Brown bread } \\
\text { Margarine } \\
\text { Jelly, apple } \\
\text { Lemonade } \\
\text { Sucrose }\end{array}$ & $\begin{array}{r}200 \\
60 \\
14 \\
10 \\
240 \\
120\end{array}$ & $\begin{array}{l}\text { Citrus salad } \\
\text { Bread } \\
\text { Margarine } \\
\text { Jelly, grape } \\
\text { Lemonade } \\
\text { Sucrose }\end{array}$ & $\begin{array}{r}200 \\
20 \\
10 \\
10 \\
240 \\
120\end{array}$ & $\begin{array}{l}\text { Plums } \\
\text { Bread } \\
\text { Margarine } \\
\text { Jelly, apple } \\
\text { Lemonade } \\
\text { Sucrose }\end{array}$ & $\begin{array}{r}200 \\
20 \\
10 \\
10 \\
240 \\
120\end{array}$ \\
\hline \multicolumn{8}{|c|}{ Lunch } \\
\hline $\begin{array}{l}\text { Tomato rice soup } \\
\text { Crackers } \\
\text { Salad: } \\
\text { Lettuce } \\
\text { Pepper } \\
\text { Spinach } \\
\text { Salad dressing: } \\
\text { Oil } \\
\text { Vinegar } \\
\text { Sugar wafers } \\
\text { Lemonade }\end{array}$ & $\begin{array}{r}200 \\
20 \\
\\
20 \\
20 \\
10 \\
10 \\
10 \\
30 \\
200\end{array}$ & $\begin{array}{l}\text { Cream celery soup } \\
\text { Crackers } \\
\text { Margarine } \\
\text { Potato salad } \\
\text { Lemon sherbet } \\
\text { Sugar wafers } \\
\text { Icing }\end{array}$ & $\begin{array}{r}200 \\
20 \\
5 \\
120 \\
200 \\
90 \\
30\end{array}$ & $\begin{array}{l}\text { Clam chowder } \\
\text { Crackers } \\
\text { Margarine } \\
\text { Fruit salad: } \\
\quad \text { Lettuce } \\
\text { Peaches } \\
\text { Pears } \\
\text { Orange sherbet } \\
\text { Crescents }\end{array}$ & $\begin{array}{r}200 \\
10 \\
10 \\
\\
5 \\
100 \\
100 \\
150 \\
72\end{array}$ & $\begin{array}{l}\text { Vegetable soup } \\
\text { Crackers } \\
\text { Brown bread } \\
\text { Fruit salad: } \\
\quad \text { Lettuce } \\
\text { Apricots } \\
\text { Pineapple cubes } \\
\text { Salad dressing } \\
\text { Cranberry sherbet }\end{array}$ & $\begin{array}{r}200 \\
10 \\
30 \\
\\
5 \\
60 \\
60 \\
15 \\
200\end{array}$ \\
\hline \multicolumn{8}{|c|}{ Dinner } \\
\hline $\begin{array}{l}\text { Potatoes, candied } \\
\text { Roast pork } \\
\text { Gravy } \\
\text { Green beans } \\
\text { Bread } \\
\text { Margarine } \\
\text { Pineapple sherbet } \\
\text { Shortbread cookies }\end{array}$ & $\begin{array}{r}100 \\
100 \\
43 \\
100 \\
20 \\
10 \\
150 \\
45\end{array}$ & $\begin{array}{l}\text { Pan-fried, round } \\
\text { steak (ground) } \\
\text { Margarine } \\
\text { Potatoes } \\
\text { Tomatoes } \\
\text { Bread } \\
\text { Maple tapioca }\end{array}$ & $\begin{array}{r}80 \\
30 \\
100 \\
100 \\
25 \\
150\end{array}$ & $\begin{array}{l}\text { Shrimp } \\
\text { Margarine } \\
\text { Catsup } \\
\text { Potatoes } \\
\text { Onions } \\
\text { Bread } \\
\text { Caramels } \\
\text { Chocolate pudding } \\
\text { Lemonade }\end{array}$ & $\begin{array}{r}80 \\
30 \\
35 \\
135 \\
50 \\
20 \\
30 \\
200 \\
100\end{array}$ & $\begin{array}{l}\text { Veal steak } \\
\text { Margarine } \\
\text { Potatoes } \\
\text { Beets } \\
\text { Bread } \\
\text { Sugar cookies } \\
\text { Icing } \\
\text { Punch }\end{array}$ & $\begin{array}{r}75 \\
30 \\
100 \\
100 \\
20 \\
100 \\
40 \\
280\end{array}$ \\
\hline
\end{tabular}

* Tea, coffee, spices, and a noncaloric carbonated beverage were allowed ad libitum.

(Table I). These four menus supplied an average of $32.5 \mathrm{~g}$ of protein per day $(\mathrm{N} \times 6.25)$ by analysis and were calculated to supply approximately 2,800 calories per man daily. The diet for the high protein period was identical except that $100 \mathrm{~g}$ of dried, desugared egg white (a fat- and cholesterol-free protein source) was substituted isocalorically for sucrose. Thus, the amount and type of fat in the diet, a mixture of animal and vegetable fat, remained constant throughout the study. The amounts of protein, fat, calories, and cholesterol supplied during each period are presented in Table II. The sub-

TABLE II

Daily nutrients consumed per subject

\begin{tabular}{|c|c|c|c|}
\hline & \multicolumn{3}{|c|}{ Period } \\
\hline & I & II & III \\
\hline Calories* & 2,820 & 2,820 & 2,820 \\
\hline Protein, $g \dagger$ & 32.7 & 106.3 & 32.3 \\
\hline Protein, \% calories & 4.6 & 15.1 & 4.6 \\
\hline Fat, $g \dagger$ & 97 & 105 & 111 \\
\hline Fat, \% calories & 31.0 & 33.5 & 35.4 \\
\hline Cholesterol, $m g \dagger$ & 185 & 180 & 198 \\
\hline
\end{tabular}

* Calculated values.

† Determined values. jects were fed weighed amounts of each menu which they consumed completely. In addition to the regular menus coffee and tea without cream or sugar and a noncaloric carbonated beverage were allowed ad libitum. In order to minimize dietary variations during the study, all foods were initially obtained in sufficient quantities to last the entire 12-week period.

A composite representing the total daily intake of one subject was taken for each of the four menus twice during each of the three periods. The diet composites were analyzed for nitrogen by the conventional macro-Kjeldahl technique, for fat by an acid hydrolysis procedure (18), and for Lieberman-Burchard positive sterols (19) with a correction for fast-acting sterols as described by Moore and Baumann (20). The energy content of diets was calculated. Fasting heparinized blood samples were drawn by venipuncture every 7 days. The plasma was separated from the cells and the lipids extracted with chloroform: methanol $(2: 1)$. Moisture was removed from the lipid extract with anhydrous sodium sulfate and the lipids were dissolved in petroleum ether $\left(\mathrm{bp} 70^{\circ} \mathrm{C}\right.$ ). The lipids were fractionated by silicic acid chromatography (21). A $10 \times 300 \mathrm{~mm}$ column, with sintered glass plate equipped with a water jacket, was employed. The column was packed with $2 \mathrm{~g}$ of silicic acid, and cold tap water was circulated through the water jacket. The 
column was washed successively with $5 \mathrm{ml}$ ethyl ether, $15 \mathrm{ml}$ ethyl ether: acetone (1:1), $10 \mathrm{ml}$ ethyl ether, and $50 \mathrm{ml}$ petroleum ether (bp $70^{\circ} \mathrm{C}$ ). The lipid sample dissolved in petroleum ether was applied to the column and washed with a small amount of petroleum ether. The lipids were then eluted in three fractions : fraction I containing cholesterol esters was eluted with $35 \mathrm{ml}$ of 1 per cent ethyl ether in petroleum ether; fraction II containing free cholesterol and mono-, di-, and triglycerides was eluted with $30 \mathrm{ml}$ of ethyl ether; and fraction III containing phospholipids was eluted with $20 \mathrm{ml}$ of 35 per cent methanol in chloroform followed by $40 \mathrm{ml}$ of methanol. The appropriate eluted fractions were analyzed for cholesterol (22), lipid phosphorus (23), and total glycerides (24). The total glyceride procedure employed is a modification of the procedure described by Van Handel and Zilversmit (25) which involves the removal of cholesterol, since it has been shown to interfere with the final color development (24). Serum was obtained from a second blood sample taken every 7 days for total protein analysis by the method of Gornall, Bardawill and David (26); 48-hour urine and 96-hour stool samples were collected. The stool specimens were homogenized; urine volumes were recorded. Aliquots of the stool and urine samples were analyzed for nitrogen by a macroKjeldahl procedure. The stool samples were also analyzed for bile acids (27) and total sterols (22).
RESULTS

Table III presents data on body weight, nitrogen balance, and total serum proteins, as mean values for the seven subjects unless otherwise noted. There was a progressive weight loss throughout the study, most marked during the low protein periods; the weight loss during the high protein period was negligible. The negative nitrogen balance noted on the low protein intake was expected ; the same is true of the positive balance observed during the high protein period. The subjects approached nitrogen balance after 16 days on each diet, and the nitrogen balance remained relatively constant for the remainder of the experimental period, indicating that the subjects had adjusted, or nearly so, to the dietary nitrogen levels. The serum protein values presented in Table III also follow the expected trend, with the possible exception of the lack of change during the second low protein period.

The influence of the dietary protein levels employed on plasma lipids is shown in Table IV.

TABLE III

Mean nitrogen balance, serum protein, and body weight data for seven subjects fed experimental diets *

\begin{tabular}{|c|c|c|c|c|}
\hline $\begin{array}{c}\text { Protein } \\
\text { intake }\end{array}$ & $\begin{array}{l}\text { Day of } \\
\text { study }\end{array}$ & $\mathrm{N}$ balance & Serum protein & Body weight \\
\hline $\begin{array}{c}g / d a y \\
33\end{array}$ & $\begin{array}{r}0 \\
7 \\
8 \\
14 \\
16 \\
21 \\
24 \\
28\end{array}$ & $\begin{array}{c}g / d a y \\
\\
-2.46 \pm 2.00 \dagger \\
-1.34 \pm 0.93 \\
-0.80 \pm 1.18 \\
-0.23 \pm 0.72\end{array}$ & $\begin{array}{c}g / 100 \mathrm{ml} \\
7.16 \pm 0.35 \\
7.01 \pm 0.50 \\
6.82 \pm 0.44 \\
6.67 \pm 0.30 \\
6.32 \pm 0.26\end{array}$ & $\begin{array}{c}\mathrm{kg} \\
77.5 \pm 9.6 \\
76.8 \pm 9.3 \\
75.9 \pm 9.2 \\
75.6 \pm 8.6 \\
74.9 \pm 8.9\end{array}$ \\
\hline 106 & $\begin{array}{l}35 \\
36 \\
42 \\
44 \\
49 \\
52 \\
56\end{array}$ & $\begin{array}{l}4.03 \pm 1.30 \\
1.56 \pm 1.05 \\
0.74 \pm 0.61 \dagger \\
1.33 \pm 1.00 \ddagger\end{array}$ & $\begin{array}{l}7.17 \pm 0.56 \\
7.47 \pm 0.29 \\
7.25 \pm 0.46 \\
7.16 \pm 0.37\end{array}$ & $\begin{array}{l}74.8 \pm 8.8 \\
74.7 \pm 8.8 \\
74.6 \pm 8.4 \\
74.2 \pm 8.6\end{array}$ \\
\hline 32 & $\begin{array}{l}63 \\
64 \\
70 \\
72 \\
77 \\
80 \\
84\end{array}$ & $\begin{array}{r}-1.97 \pm 1.12 \\
-0.57 \pm 0.86 \\
-0.23 \pm 0.61 \\
-0.59 \pm 0.74\end{array}$ & $\begin{array}{l}7.03 \pm 0.34 \\
7.39 \pm 0.58 \\
7.12 \pm 0.54 \\
7.21 \pm 0.24\end{array}$ & $\begin{aligned} 73.9 & \pm 8.0 \\
73.5 & \pm 8.2 \\
73.4 & \pm 7.8 \\
72.8 & \pm 7.9\end{aligned}$ \\
\hline
\end{tabular}

* Mean for seven subjects \pm standard deviation unless otherwise noted. Each value is a mean value determined for the period elapsed between values in the table, 8 or 4 days.

$\dagger$ Mean for six subjects.

$\ddagger$ Mean for three subjects, 
TABLE IV

Influence of dietary protein intake on plasma lipids of human subjects *

\begin{tabular}{|c|c|c|c|c|c|c|}
\hline \multirow{3}{*}{$\begin{array}{l}\text { Protein } \\
\text { intake }\end{array}$} & \multirow{3}{*}{$\begin{array}{l}\text { Week } \\
\text { of } \\
\text { study }\end{array}$} & \multicolumn{5}{|c|}{ Plasma lipid, $\mathrm{mg} / 100 \mathrm{ml}$} \\
\hline & & \multicolumn{3}{|c|}{ Cholesterol } & \multirow{2}{*}{$\begin{array}{l}\text { Lipid } \\
\text { phosphorus } \\
\times 25\end{array}$} & \multirow[b]{2}{*}{ Glycerides $\dagger$} \\
\hline & & Ester & Free & Total & & \\
\hline \multicolumn{7}{|l|}{ g/day } \\
\hline 33 & $\begin{array}{l}0 \\
1 \\
2 \\
3 \\
4\end{array}$ & $\begin{array}{l}135 \pm 10 \\
121 \pm 8 \\
115 \pm 7 \\
125 \pm 10 \\
112 \pm 20\end{array}$ & $\begin{array}{l}66 \pm 4 \\
66 \pm 11 \\
57 \pm 7 \\
61 \pm 11 \\
59 \pm 9\end{array}$ & $\begin{array}{l}201 \pm 18 \\
187 \pm 16 \\
172 \pm 14 \\
186 \pm 12 \\
171 \pm 26\end{array}$ & $\begin{array}{l}223 \pm 30 \\
192 \pm 28 \\
170 \pm 32 \\
174 \pm 30 \\
182 \pm 42\end{array}$ & $\begin{array}{l}94 \pm 55 \\
75 \pm 30 \\
96 \pm 31 \\
98 \pm 43 \\
98 \pm 56\end{array}$ \\
\hline 106 & $\begin{array}{l}5 \\
6 \\
7 \\
8\end{array}$ & $\begin{array}{l}129 \pm 25 \\
125 \pm 10 \\
121 \pm 11 \\
120 \pm 10\end{array}$ & $\begin{array}{l}64 \pm 17 \\
60 \pm 6 \\
63 \pm 14 \\
50 \pm 6\end{array}$ & $\begin{array}{l}193 \pm 41 \\
185 \pm 15 \\
185 \pm 21 \\
171 \pm 21\end{array}$ & $\begin{array}{l}161 \pm 36 \\
159 \pm 25 \\
166 \pm 26 \\
166 \pm 22\end{array}$ & $\begin{array}{l}139 \pm 74 \\
144 \pm 58 \\
154 \pm 76 \\
175 \pm 44\end{array}$ \\
\hline 32 & $\begin{array}{r}9 \\
10 \\
11 \\
12\end{array}$ & $\begin{array}{l}115 \pm 12 \\
120 \pm 10 \\
128 \pm 22 \\
123 \pm 8\end{array}$ & $\begin{array}{l}66 \pm 14 \\
62 \pm 5 \\
61 \pm 14 \\
57 \pm 6\end{array}$ & $\begin{array}{l}182 \pm 23 \\
183 \pm 14 \\
189 \pm 35 \\
180 \pm 14\end{array}$ & $\begin{array}{l}165 \pm 30 \\
183 \pm 22 \\
172 \pm 40 \\
170 \pm 32\end{array}$ & $\begin{array}{l}131 \pm 23 \\
150 \pm 34 \\
155 \pm 40 \\
120 \pm 18\end{array}$ \\
\hline
\end{tabular}

* Mean value for seven subjects \pm standard deviation.

$\dagger$ Glyceride glycerol ( $\mathrm{m}$ moles/L plasma) $\times 88.5$ (molecular weight of triolein assumed).

There was an initial decrease in plasma cholesterol (total and ester) and in phospholipids. This deviation is typical of adaptive changes previously observed in these subjects. Plasma glycerides, however, remained unchanged. Increasing the protein intake from 33 to $106 \mathrm{~g}$ per day did not result in any statistically significant change in plasma cholesterol or phospholipid levels, but did result in a statistically significant increase in plasma glycerides. When the subjects were returned to the low protein intake the plasma lipids remained unaltered.

The variation in protein intake in this study, then, did not significantly influence any of the plasma lipid components determined other than plasma glycerides, and the changes in the latter did not parallel changes in dietary protein levels. Furthermore, no significant differences were noted in bile acid or sterol excretion.

\section{DISCUSSION}

The results of the present study, demonstrating a lack of effect of dietary protein on the plasma cholesterol levels of human subjects, are in agreement with the report of Keys and Anderson (14), but differed from their study in that a greater range of protein intake was employed and the percentage of calories coming from fat was higher. The results of the present investigation, however, do not agree with those of Olson (16) or Al- banese and co-workers (15), who observed a positive relationship between dietary protein intake and serum cholesterol levels. The reasons for this lack of agreement are not readily evident. The results of the study of the Albanese group are complicated by the lack of control of the diets consumed. Olson employed rather short experimental periods ( 1 to 2 weeks) and his results may reflect transient changes. An indication of such changes, particularly in going from a low to a high protein diet, appears in our data in Table IV, week 5 , where six of the seven subjects demonstrated elevated plasma cholesterol levels after consuming the high protein diet for 1 week. Other factors that may have complicated Olson's study are the cholesterol content and fatty acid composition of the dietary fat, which differed in the various diet periods. The changes observed in plasma glyceride levels are difficult to interpret and do not appear to be the result of dietary protein intake because of the lack of change when the subjects were switched from the high to the low protein diet (Table IV).

The results of the present work might be criticized because of the loss of weight observed throughout the study. However, available data for the growing rat indicate that caloric restriction per se has little or no effect on plasma cholesterol levels (28). The results herein reported are interpreted as supporting the concept that 
dietary protein does not influence plasma lipid levels in human subjects, at least within the range of the protein intake employed.

\section{SUMMARY}

A group of seven healthy, male volunteers was maintained for 12 weeks on a rigidly controlled diet varying in the amount of protein. The subjects were stabilized on a low protein diet, were changed to a high protein diet, then returned to the low protein diet; each dietary period was of 4 weeks' duration. The subjects were in negative nitrogen balance during both low protein periods and in positive balance during the high protein period.

Dietary protein did not significantly influence plasma cholesterol (free, ester, or total) or phospholipids. Plasma glycerides were elevated when the subjects were changed from the low to the high dietary protein level but remained elevated when the dietary protein intake was returned to the low level.

\section{ACKNOWLEDGMENTS}

The authors express their gratitude to Richard $\mathrm{S}$. Harding and James W. Shockley for analytical assistance and to Gerhard J. Isaac for statistical analyses. The volunteer subjects used for this study were provided through the cooperation of Dr. Norman F. Witt, Professor of Chemistry, University of Colorado, and The Surgeon General, U. S. Army (Contract DA-49-007MD-549).

\section{REFERENCES}

1. Barnes, R. H., Kwong, E., Pond, W., Lowry, R., and Loosli, J. K. Dietary fat and protein and serum cholesterol. II. Young swine. J. Nutr. 1959, 69, 269.

2. DeGroot, A. P. Dietary protein and serum cholesterol in rats. Nature (Lond.) 1959, 184, 903.

3. Leveille, G. A., Feigenbaum, A. S., and Fisher, H. The effect of dietary protein, fat and cholesterol on plasma cholesterol and serum protein components of the growing chick. Arch. Biochem. $1960,86,67$.

4. Leveille, G. A., and Sauberlich, H. E. Influence of dietary protein level on serum protein components and cholesterol in the growing chick. J. Nutr. 1961, 74, 500.

5. Moyer, A. W., Kritchevsky, D., Logan, J. B., and Cox, H. R. Dietary protein and serum cholesterol in rats. Proc. Soc. exp. Biol. (N. Y.) 1956, 92, 736.

6. Nishida, T., Takenaka, F., and Kummerow, F. A. Effect of dietary protein and heated fat on serum cholesterol and beta-lipoprotein levels, and on the incidence of experimental atherosclerosis in chicks. Circulat. Res. 1958, 6, 194.

7. Mann, G. V., Andrus, S. B., McNally, A., and Stare, F. J. Experimental atherosclerosis in Cebus monkeys. J. exp. Med. 1953, 98, 195.

8. Seidel, J. C., Nath, N., and Harper, A. E. Diet and cholesterolemia: V. Effects of sulfur containing amino acids and proteins. J. Lip. Res. 1960, 1, 474.

9. Fillios, L. C., and Mann, G. V. Influence of sulfur amino acid deficiency on cholesterol metabolism. Metabolism 1954, 3, 16.

10. Johnson, D., Jr., Leveille, G. A., and Fisher, H. Influence of amino acid deficiencies and protein level on the plasma cholesterol of the chick. J. Nutr. 1958, 66, 367.

11. Olson, R. E., Jablonski, J. R., and Taylor, E. The effect of dietary protein, fat, and choline upon the serum lipids and lipoproteins of the rat. Amer. J. clin. Nutr. 1958, 6, 111.

12. Lucas, C. C. Lipotropic factors in transport of cholesterol in experimental animals. Amer. J. clin. Nutr. 1960, 8, 315.

13. Hegsted, D. M., Mills, R. C., Elvehjem, C. A., and Hart, E. B. Choline in the nutrition of chicks. J. biol. Chem. 1941, 138, 459.

14. Keys, A., and Anderson, J. T. Dietary protein and the serum cholesterol level in man. Amer. J. clin. Nutr. 1957, 5, 29.

15. Albanese, A. A., Higgons, R. A. Lorenze, E. J., and Orto, L. A. Effects of dietary proteins on blood cholesterol levels of adults. Geriatrics 1959, 14, 237.

16. Olson, R. E. Effect of dietary protein upon fat transport. Diabetes 1958, 7, 202.

17. Walker, G. R., Morse, E. H., and Overley, V. A. The effect of animal protein and vegetable protein diets having the same fat content on the serum lipid levels of young women. J. Nutr. 1960, 72, 317.

18. Official Methods of Analysis, 8th ed. Washington, D. C., Association of Official Agricultural Chemists, 1955.

19. Schoenheimer, R., and Sperry, W. M. A micromethod for the determination of free and combined cholesterol. J. biol. Chem. 1934, 106, 745.

20. Moore, P. R., and Baumann, C. A. Skin sterols: I. Colorimetric determination of cholesterol and other sterols in skin. J. biol. Chem. 1952, 195, 615.

21. Leveille, G. A., Shockley, J. W., and Sauberlich, H. E. A micromethod for the separation of lipid mixtures by silicic acid chromatography. U. S. Army Med. Res. and Nutr. Lab. Report 254, October, 1960.

22. Searcy, R. L., and Bergquist, L. M. A new color reaction for the quantitation of serum cholesterol. Clin. chim. Acta 1960, 5, 192. 
23. Fiske, C. H., and Subbarow, Y. The colorimetric determination of phosphorus. J. biol. Chem. 1925, $66,375$.

24. Leveille, G. A., Shockley, J. W., and Sauberlich, H. E. The influence of cholesterol on the determination of serum glycerides. U. S. Army Med. Res. and Nutr. Lab. Report 255, February, 1961.

25. Van Handel, E., and Zilversmit, D. B. Micromethod for the direct determination of serum triglycerides. J. Lab. clin. Med. 1957, 50, 152.
26. Gornall, A. G., Bardawill, C. J., and David, M. M. Determination of serum proteins by means of the biuret reaction. J. biol. Chem. 1949, 177, 751.

27. Haust, H. L., and Beveridge, J. M. R. Effect of varying type and quantity of dietary fat on the fecal excretion of bile acids in humans subsisting on formula diets. Arch. Biochem. 1958, 78, 367.

28. Okey, R., Lyman, M. M., and Einset, B. M. Effect of food restriction on cholesterol metabolism. 1. Moderate limitation during late adolescence. J. Amer. diet. Ass. 1959, 35, 115. 